\title{
PŘÍNOS NÁLEZU DENÁRU BOLESLAVA III. K OTÁZCE POLOHY A VZNIKU KOSTELŮ SV. VÁCLAVA A MARTINA VE STARÉ PLZNI
}

\author{
JIŘÍ ORNA - VERONIKA DUDKOVÁ
}

\begin{abstract}
Abstrakt: V letech 2012-2017 proběhl v levobřežní části Starého Plzence záchranný archeologický výzkum v prostoru zaniklého Blochova statku. Významná chronologická zjištění přinesl hlavně odkryv hrobu 14, který byl součástí zkoumaného pohřebního areálu. Na základě rozboru těchto chronologických zjištěni a jejich komparace s dosavadním stavem poznáni je vytvořen nástin rekonstrukce topografie a chronologie vývoje levobřežní části někdejši premyslovské sídelní aglomerace, především pak zaniklých kostelů sv. Václava a sv. Martina. Ty jsou známy pouze diky uvedení v listině Přemysla Otakara II. z roku 1266.
\end{abstract}

Klíčová slova: kostel - hrob-obolus mrtvých-denár-radiokarbonové datování.

The contribution of the find of a dinar of Boleslav III to the question of the location and origin of the Church of St. Wenceslas and the Church of St. Martin in Old Plzen̆

\begin{abstract}
Rescue archaeological research was conducted in 2012-2017 in the left-bank section of Starý Plzenec, on the site of the former Bloch homestead. Major chronological findings were yielded, in particular, in connection with grave 14 which was part of an investigated burial ground. The analysis of the chronological data and its comparison with the existing information resulted in an outline of the reconstruction of the topography and chronology of the development of the left-bank area of a former Premyslid agglomeration, especially the now non-existent Church of St. Wenceslas and the Church of St. Martin. These structures are only known thanks to a mention in a decree of King Přemysl Otakar II from 1266.
\end{abstract}

Key words: church-grave-Charon's obol-dinar-radiocarbon dating.

\section{Úvod}

Pro poznání období středověku je velmi podstatné propojení a komparace archeologických a historických pramenů. Archeologové věnující se tomuto období se velmi často snaží o datování zachycených situací tak, aby časový úsek odpovídal historickým pramenům (Profantovi 2003, 242). Kalendářově jasně určené události se však stávají spíše součástí archeologicky vymezeného poměrně dlouhého časového intervalu (Klápště 2003, 101). Archeologie se ovšem neomezuje pouze na získání chronologických dat, přináší také možnost poznání prostorového chování někdejších obyvatel (Klápště 2003, 103). Na základě tohoto poznání jsou vytvářeny pokusy o rekonstrukci topografie historických sídel, a to i zaniklých.

Získávání významných poznatků není vázáno pouze na výzkumy systematické, ale přináší je i ty záchranné. Stejně tak nehraje roli ani rozsah výzkumu. To dokládá záchranný archeologický výzkum realizovaný mezi lety 2012 a 2017 v levobřežní části dnešního Starého Plzence, někdejší (Staré) Plzně. Jeho zjištění právě v propojení a komparaci s historickými prameny, v tomto případě s listinou Přemysla Otakara II. z roku 1266, přispívají k rekonstrukci topografie severní části někdejšího levobřežního suburbia a nástinu jeho možného chronologického vývoje, především pak k otázce polohy a vzniku zaniklých kostelů sv. Václava a sv. Martina. Tato otázka je řešena již od poloviny 18. století, kdy benediktinský historik Bonaventura Piter sepsal historiografickou studii o (Staré) Plzni (Šváb ed. 1988).

\section{Stručný nástin historie (staro)plzeňského levobřeží v období 10.-13. století}

V období 10.-13. století byl centrem přemyslovské správy v západních Čechách hrad Plzeň. Někteří badatelé předpokládají, že regionální centrum na vrchu Hůrka vzniklo již v 9. století (Bašta-Baštová 1988, 27; Doubová 1990, 33-34). Nejstarší písemnou zprávou o plzeňském hradu 
(Pilisini urbs) je zápis v kronice merseburského biskupa Thietmara, ve kterém autor popisuje porážku vojska císaře Oty II. roku 976 a dokládá př́slušnost Plzně k přemyslovské doméně (Chronicon Thietmari 1996, 104-105).

Na opačném, tj. levém břehu řeky Úslavy se na ploše celé střední části terasového stupně III (Štafl 1957, mapa 1) nacházelo neopevněné suburbium. V jeho prostoru se objevují nálezy již ze sklonku středohradištního období (Frýda-Hus 1989, 223, obr. 6:1). Intencionální preurbánní osídlení zřejmě tvořily osady související s vlastnickými, popřípadě korporativními kostely s vazbou na sídla velmožů a významných hradských úředníků (Široký-Nováček-Kaiser 2004, 809). Tyto sakrální stavby jsou známy díky listině Přemysla Otakara II. z roku 1266, která stvrzuje, že panovník věnoval chotěšovskému klášteru plzeňské kostely (CDB V/1, č. 475). V prostoru levobřežní aglomerace se nacházely čtyři z nich. Dodnes stojí pouze kostel sv. Jana Křtitele. Za doklad jeho raně středověké stavební fáze jsou považovány nepravidelnosti v severní stěně lodi (Široký-Nováček 2014, 111) a zmínka o výskytu kvádříkového zdiva (Merhautová 1971, 324). Kostel sv. Blažeje byl součástí osady zvané v listině Crabbocon (více Beneš-Richter 1976, 68, 72; Rožmberský 1998). Polohu zbylých dvou kostelů, sv. Martina a sv. Václava, se podařilo určit na základě archeologických dokladů pohřebních areálů (Beneš-Richter 1976, 68; Široký-NováčekKaiser 2004, 810). Obě sakrální stavby se zřejmě nacházely zhruba 150 metrů od sebe na spodním okraji terasového stupně III (Široký-Nováček-Kaiser 2004, 810).

K největšímu rozvoji levobřežního suburbia s trojicí kostelů pravděpodobně došlo po polovině 13. století, kdy byla k jeho jihozápadnímu okraji připojena ortogonálně rozvržená část městského charakteru (Široký-Nováček-Kaiser 2004, 813). Jak v již zmíněné listině Přemysla Otakara II., tak v listině papeže Řehoře X. z roku 1273 (CDB V/2, č. 708, 353-354) je Plzeň označována jako civitas, jehož součástí je forum. V devadesátých letech 13. století došlo k nekatastrofickému zániku tohoto osídlení, který způsobil odchod obyvatel do nově založeného královského města Nový Plzeň (Široký-Nováček-Kaiser 2004, 817).

\section{Záchranný archeologický výzkum}

Záchranný archeologický výzkum na místě Blochova statku (čp. 88, obr. 1) byl vyvolán záměrem výstavby luxusního bytového domu a probíhal od srpna 2012 do července 2017 (Orna 2018). Jeho průběh negativně ovlivnila změna osoby investora, s kterou bylo spojeno několikaleté přerušení realizace archeologického výzkumu a částečná změna projektu stavby. Plocha výzkumu byla vymezena trojúhelníkem ulic Husova, Svatopluka Čecha a Za Statkem. Vzhledem k tomu, že šlo o výzkum záchranný, odvíjela se jeho metoda od stavebního záměru. V severní části plochy (obr. 2), určené k výstavbě parkovacích míst v zahloubeném podlaží, byl výzkum realizován formou plošného odkryvu až na úroveň sterilního podloží. Ve zbylé, tedy jižní části plochy byl výzkum proveden formou odborného dohledu, nebot' výkopy pro základové pasy realizovaného stavebního objektu probíhaly v místě původních základů novověké zemědělské usedlosti.

Severní plocha byla formou plošného odkryvu zkoumána ve dvou etapách. V její východní části, kde původně stála lehká zemědělská stavba, bylo vytyčeno pět statických sond. V západní části, kde stála částečně podsklepená novostavba z třicátých let 20 . století, byla plošně zkoumána plocha skrytá po destrukci této budovy. V rámci uvedeného plošného výzkumu byly odkryty především zahloubené objekty sídlištního charakteru. Dalších patnáct objektů v severovýchodní části zkoumané plochy bylo označeno jako hroby, při antropologickém zpracování se však u dvou z nich ukázalo, že šlo pouze o shluk izolovaných kostí (Šneberger 2015, 2). U odkrytých hrobů bylo evidováno jejich překrývání.

\section{Chronologická zjištění záchranného archeologického výzkumu}

První a interpretačně jednodušší chronologické zjištění se týká zánikového horizontu zkoumaného sídelního areálu. Velmi analogické nálezové situace byly evidovány při archeologických 


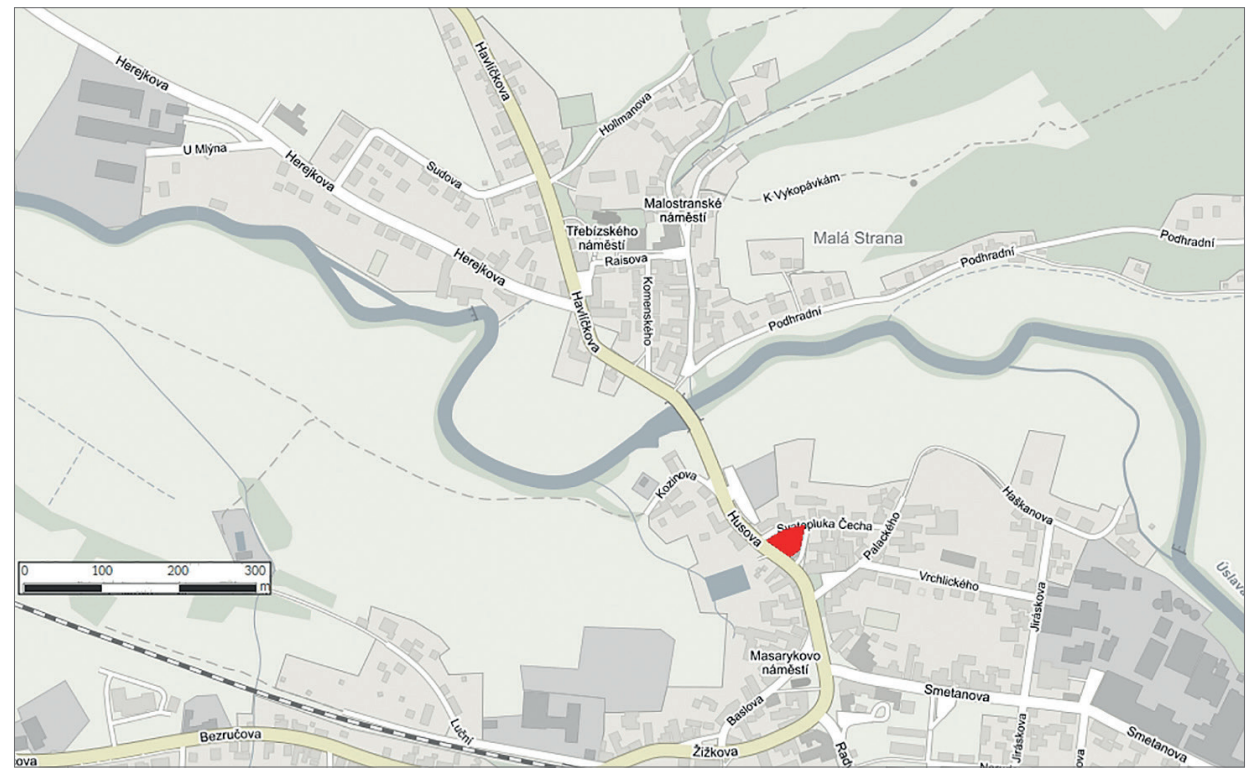

Obr. 1. Lokalizace plochy výzkumu v plánu Starého Plzence. Autor V. Dudková.

Abb. 1. Lokalisierung der Grabungsfläche in einem Plan von Altpilsen. Erstellt von V. Dudková.

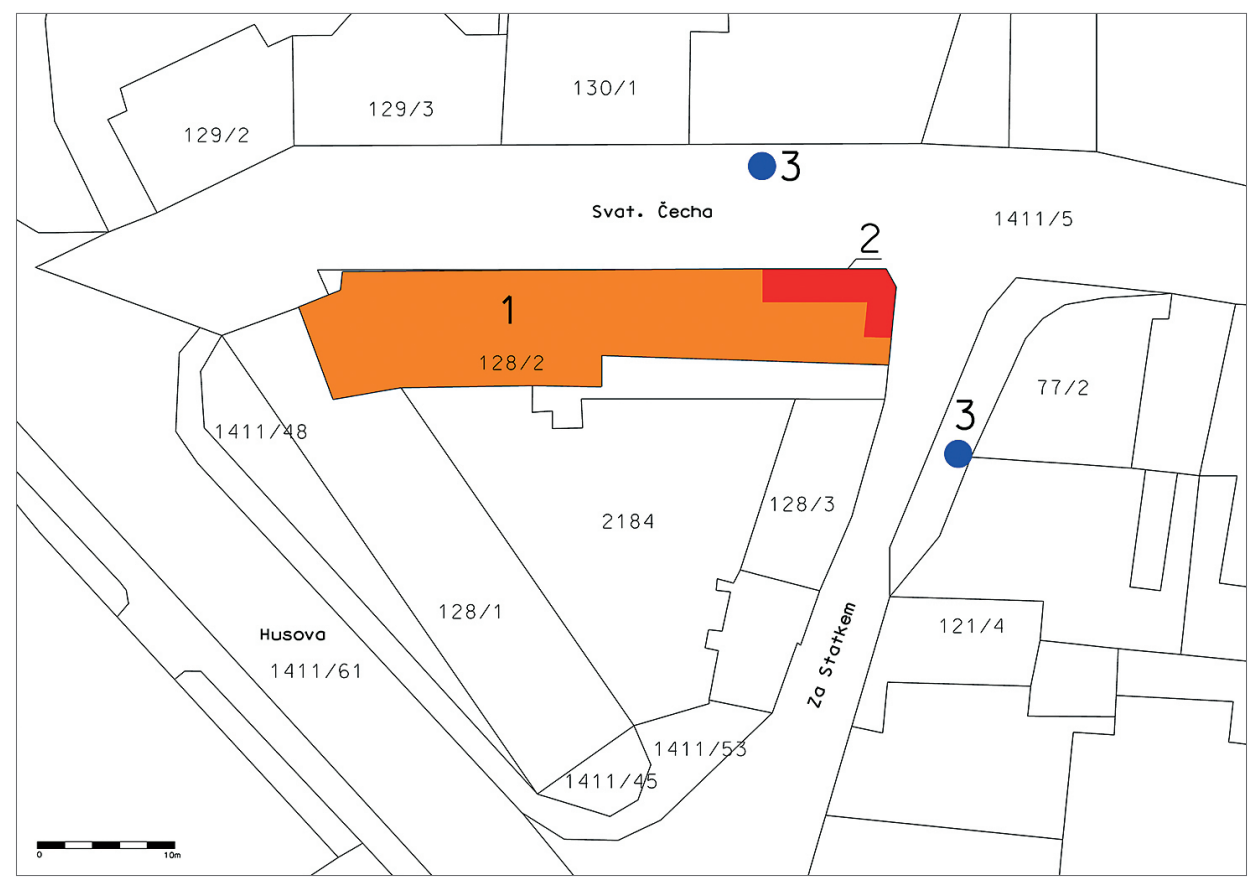

Obr. 2.1 - vyznačení rozsahu plošného odkryvu; 2 - zkoumaný pohřební areál; 3 - starší nálezy hrobů (podle Široký-Nováček-Kaiser 2004, 808, obr. 6). Orientováno k severu. Autor V. Dudková.

Abb. 2. 1 - Kennzeichnung des Umfangs der großflächigen Freilegung; 2 - untersuchtes Bestattungsareal; 3 - ältere Gräberfunde (nach Široký-Nováček-Kaiser 2004, 808, Abb. 6). Orientierung nach Norden. Erstellt von V. Dudková. 

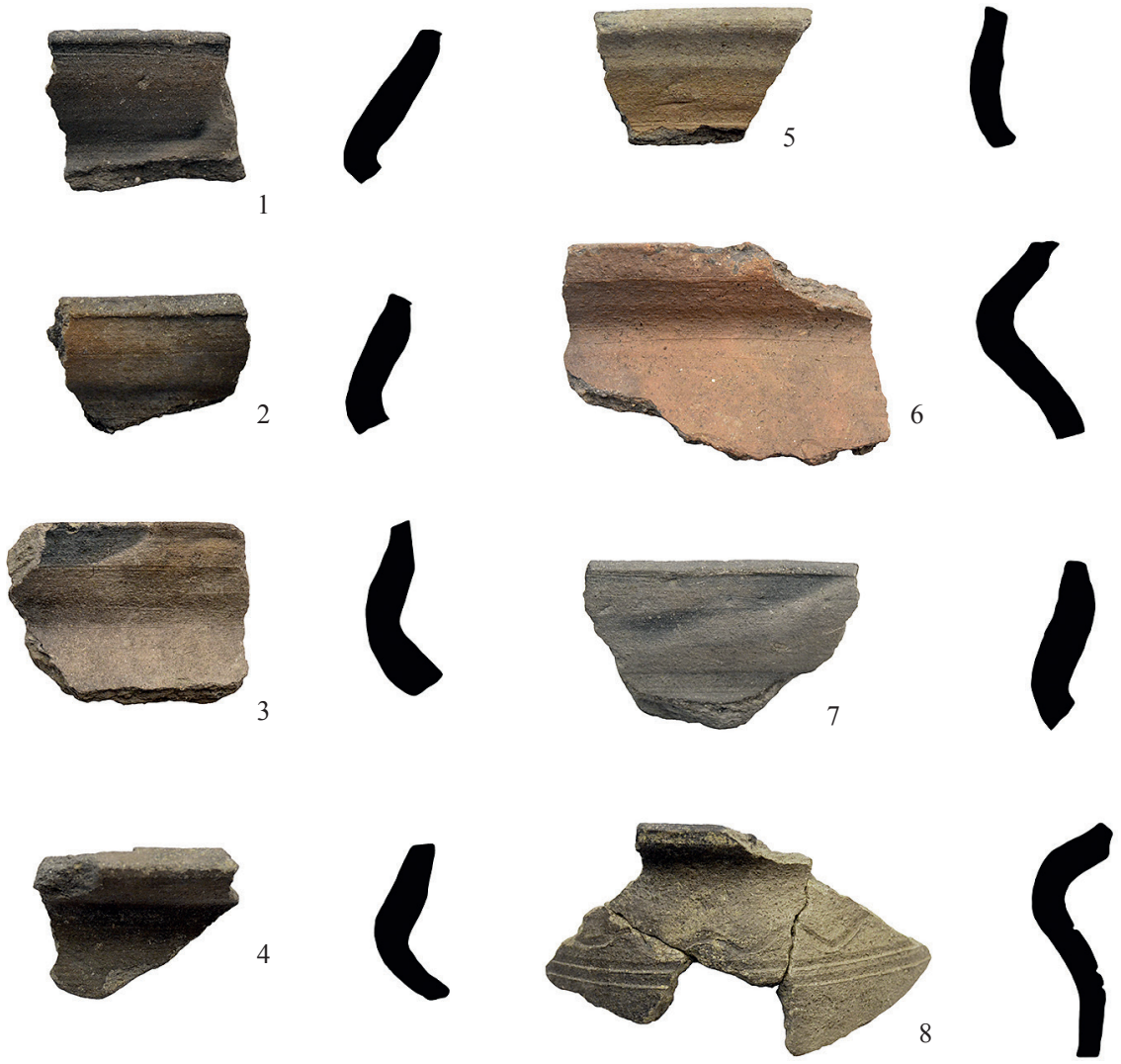

0 $5 \mathrm{~cm}$

Tab. 1. Výběr typických keramických zlomků: 1,2 - sonda 1B, k. 101; 3-5-sonda 1B, k. 502; 6, 7-sonda 1B, k. 503; 8-k. 101. Autor I. Šlechtová.

Tab. 1. Auswahl typischer Keramikfragmente: 1, 2 - Sondierungsschnitt 1B, k. 101; 3-5 - Sondierungsschnitt 1B, k. 502; 6, 7 - Sondierungsschnitt 1B, k. 503; 8 - k. 101. Erstellt von I. Šlechtová.

výzkumech na dalších místech v levobřežní části někdejší sídelní aglomerace, a to především ve Vrchlického (Beneš-Richter 1976, 69, 70; Zelenka 2010; 2012) a Smetanově ulici (Frýda-Hus 198; Široký-Nováček-Kaiser 2004, 810, 812, 818). Chronologické určení zánikového horizontu na sklonek 13. století umožňuje také nalezená keramika (tab. 1).

Další chronologické zjištění přinesl odkryv hrobu 14 (obr. 3, 4). Tento hrob byl výrazně narušen novověkou konstrukcí zděnou z lomového kamene. Ta znemožnila identifikaci původního rozsahu hrobové jámy. Při její výstavbě bylo s pohřbeným jedincem evidentně manipulováno, aby mohla být konstrukce realizována. Na kostech jsou patrná mechanická poškození, ke kterým nedošlo při záchranném archeologickém výzkumu.

Podařilo se zjistit, že pohřbený jedinec byl uložen na zádech s hlavou orientovanou k západu, přestože se nedochovala kostra lebky. Nebyly identifikovány žádné doklady pohřbu do 


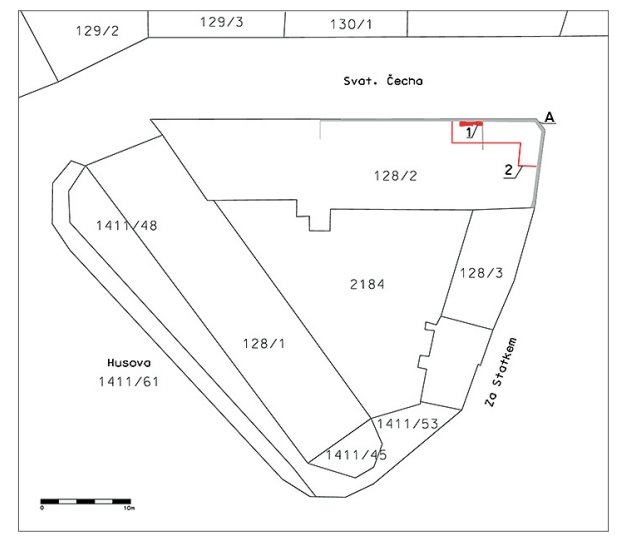

Obr. 3.1 - vyznačení polohy hrobu 14; 2 - zkoumaný pohřební areál; A - zděná konstrukce novověké lehké zemědělské stavby. Orientováno k severu. Autor V. Dudková.

Abb. 3. 1 - Kennzeichnung der Lage von Grab 14; 2 - untersuchtes Bestattungsareal; A - Mauerkonstruktion eines neuzeitlichen leichten Landwirtschaftsgebäudes. Orientierung nach Norden. Erstellt von V. Dudková.

rakve nebo uložení jedince na prkno. Vzhledem k velmi nízké kvantitativní zachovalosti kostry nebyl možný odhad pohlaví a výšky postavy, odhad věku dožití jedince zařadil do kategorie dospělých.

Součástí zásypu hrobu byla mince. Ta se nacházela přibližně $230 \mathrm{~mm}$ jihovýchodně od místa, kde lze předpokládat původní polohu pravé ruky. Z pravé horní končetiny se zachovalo jen několik rozptýlených fragmentů ruky a pažní kost natažená podél těla. Také mince mohla být ze svého původního uložení přemístěna $v$ rámci manipulace $\mathrm{s}$ ostatky při výstavbě zmíněné zděné konstrukce (Šneberger 2015, 20-22).

Nalezená mince byla určena jako denár Boleslava III. (999-1002, 1003) typu Cach (1970) č. 205 (obr. 5). Jeho rozboru z numismatického pohledu byla věnována samostatná studie (Lukas-Orna-Dudková 2016). Určení mince umožnilo chronologické zařazení hrobu, byt' se jedná pouze o datum post quem.

Přestože došlo k sekundárnímu narušení hrobu, je možné nalezenou minci označit za tzv. obolus mrtvých, záměrně vložený do hrobu zemřelé osoby, původně zřejmě do pravé dlaně. V českém prostředí byly mince nejčastěji umistovány právě do pravé ruky pohřbené osoby (Marethová 2008, 13). Za obolus mrtvých jsou považovány i nálezy mincí, které se nacházely u pravé dlaně (Klápště 1999, 778-779, tab. I; Smetánka 1967, 472) či u pravé ruky (BartoškováSláma 1997, 150, 151; Klápště 1994, 62). Při výzkumu pohřebiště ve Zdechovicích byl za minci 


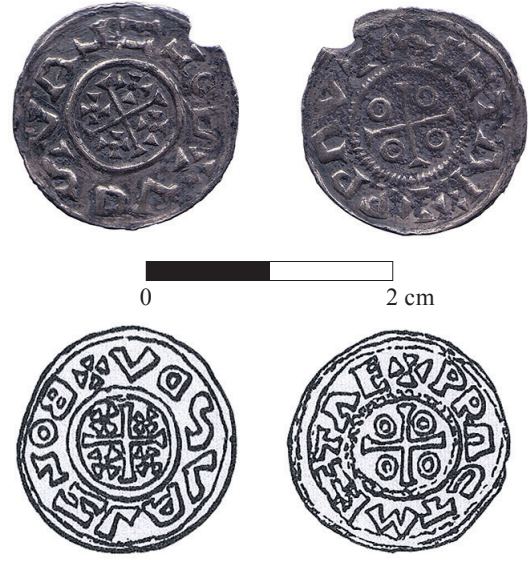

Obr. 5. Nalezený denár Boleslava III. Foto M. Zemánková. Kresba denáru typu C 205. Podle Cach 1970, č. 205.

Abb. 5. Gefundener Denar von Boleslav III. Foto M. Zemánková. Zeichnung eines Denars vom Typ C 205. Nach Cach 1970, Nr. 205.

záměrně vloženou do pravé ruky zemřelého označen nález z hrobu 45, kde se také dlaň jedince nedochovala (Horník-Bláha-Sehnoutková-Mazač 2018，27，48，99，100, obr. 43, 44). Přmésístění mince mohou vyvolat také tafonomické procesy, které u pohřbených jedinců probíhají (např. Duday-Guillon 2006; Fernández-Jalvo-Andrews 2016， 311-317; Komar-Buikstra 2008, 200-202; PinheiroCunha 2006).

Počátky zvyku záměrného vkládání mincí do hrobů se předpokládají až v období první třetiny 11. století (Bartošková 2013, 130). Nálezy starších mincí, ke kterým patř́i i nalezený denár Boleslava III., jsou označovány za solitérní (Bartošková 2013, 130), přestože nálezů těchto mincí přibývá (Lukas-Orna-Dudková 2016, 104). Stále je však nutné brát v potaz, že obolus mrtvých poskytuje u hrobu pouze datum post quem. V této souvislosti je možné uvést př́íklad z pohřebiště v Želenicích, kde se denár knížete Spytihněva II. objevil až u jednoho z nejmladších pohřbů (Turek 1947, 179).

Dále se předpokládá, že do hrobů byly vkládány aktuální mince, tedy ražby sloužící v době vložení do hrobu stále jako oběživo (Bartošková 2013, 133). Starší typy mincí však měly díky obsahu drahého kovu stabilní hodnotu, a proto jejich platnost vydržela i relativně dlouho po zavedení nového typu. Tzv. renovatio monetae se dělo až od druhé poloviny 11. století (Petráň 1998, 88).

Narušení hrobu vedlo autory výzkumu k úvaze, zda by bylo možné potvrdit, že nalezená mince mohla být opravdu jeho součástí. $Z$ tohoto důvodu byl předán vzorek jedince na radiouhlíkové datování. Vzhledem k absenci lebky musel být použit vzorek ze žebra jedince. Získaná data proto udávají období úmrtí jedince. Konvenční radiouhlíkové stáří (léta BP) bylo určeno na rok $938 \pm 25$, interval kalibrovaného stáří byl vymezen lety 1030-1156 AD s absolutní pravděpodobností $95 \%$ (Světlík 2019, tab. 2).

\section{Př́ńnos zjištění výzkumu k chronologii a topografii (staro)plzeňského levobřeží}

Zkoumaný pohřební areál je možné interpretovat jako kostelní pohřebiště, které souviselo s jednou ze zaniklých sakrálních staveb situovaných na spodním okraji terasového stupně III. Jako první se $\mathrm{k}$ poloze jednoho z kostelů, konkrétně toho s patrociniem sv. Václava, vyjádřil po polovině 18 . století Bonaventura Piter. Podle něj stála svatyně s tímto zasvěcením mimo tehdejší město, $v$ místech zahrad jeho obyvatel (Šváb ed. 1988, 54, 86). Přesnější lokalizaci jednoho z kostelů se podařilo určit na konci 19. století, a to na základě ústní tradice podpořené náhodnými nálezy kostí a dlaždic na zahradě domu čp. 80 (Koláŕ 1869, 417). Druhý kostel byl na základě obdobných nálezů situován do zahrady protilehlého čp. 81 (Beneš-Richter 1976, 68), byt' původně bylo vzhledem ke stejnému majiteli omylem uváděno čp. 58 v dnešní Smetanově ulici (Strnad 1903, 14). S ohledem na dnešní stav bádání se však pravděpodobně jednalo o doklady jednoho zaniklého pohřebního areálu.

Do prostoru Blochova statku čp. 88 údajně kladl druhý z kostelů plzeňský farář Josef Müller, byt' jde o lokalizaci poněkud zmatenou a rozporuplnou (Beran 1947, 66, pozn. 173; Beneš-Richter 1976, 73, pozn. 13). Přesto se v roce 1995 podařilo doložit existenci pohřebního areálu v severním a východním sousedství statku čp. 88 (Nováček-Široký 1996; Široký-Nováček-Kaiser 2004, 810). Při záchranném archeologickém výzkumu se v letech 2012 a 2013 v severovýchodní části areálu 
někdejšího Blochova statku podařilo odkrýt okrajovou část tohoto pohřebiště.

Nálezy dokladů pohřebišt' umožnily lokalizaci kostelů na spodní okraj terasového stupně III. Otevřena však zůstala otázka, který kostel byl zasvěcen sv. Martinovi a který sv. Václavovi, a kdy došlo $\mathrm{k}$ jejich stavbě. Tuto otázku se snažil vyřešit J. Beran, který vznik kostela sv. Martina kladl do období od konce 10. do první poloviny 11 . století, sv. Václava pak do druhé poloviny 11. století (Beran 1947, 10). Vycházel přitom z tehdy známé datace kostelů stejného patrocinia a jejich četnosti v př́slušném období v českých zemích (Beran 1947, 41, 42, pozn. 29, 30, 31). Pokud budou patrocinia těchto kostelů řešena modernějšími historiografickými výzkumy, ke vzniku kostela sv. Václava mohlo v prostoru přemyslovské sídelní aglomerace dojít až zhruba od poloviny 11. století (Boháč 1973, 378), sv. Martina nejdříve v první polovině 12. století (Boháč 1973, 382).

Pokud budou možná patrocinia kostelů komparována $\mathrm{s}$ chronologickými zjištěními

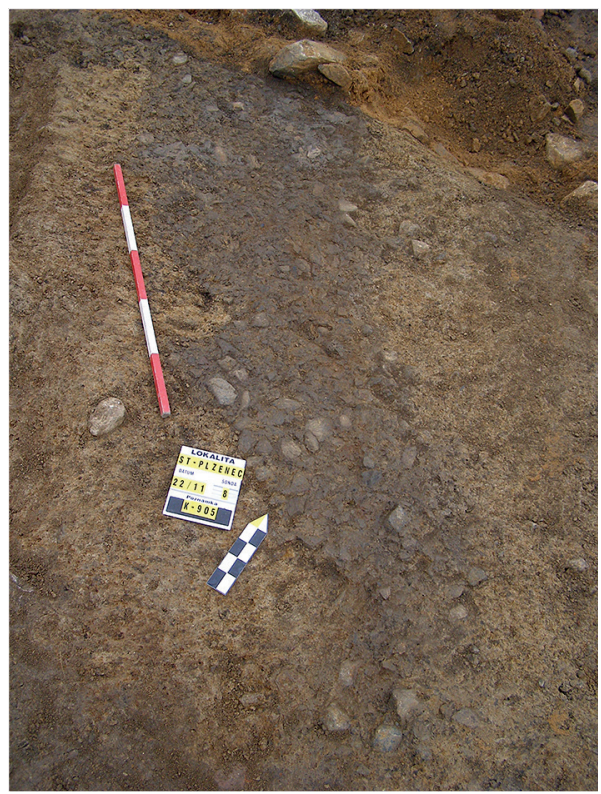

Obr. 6. Fotodokumentace štětované plochy. Autor O. Baier.

Abb. 6. Fotodokumentation der sturzgepflasterten Fläche. Autor O. Baier. získanými z hrobu 14, tedy s denárem daným datem post quem 1003 a smrtí pohřbeného jedince vymezenou radiouhlíkovým datováním

do intervalu 1030-1156, je možné se přiklonit k názoru, že pohřebiště spíše patřilo ke kostelu sv. Václava. Od poloviny 11. století ostatně kulminuje četnost mincí ukládaných do hrobu (Bartošková 2013, 130; Klápště 1999, 777; Marethová 2008, 11). To zřejmě souvisí s teritorizací mince a jejím větším uplatněním v domácím prostředí (Klápště 1999, 800).

$\mathrm{V}$ průběhu záchranného archeologického výzkumu v prostoru Blochova statku nebyly zachyceny žádné přímé doklady sakrální stavby. Určitou pomůckou při hledání kostela, pravděpodobně zasvěceného sv. Václavovi, je vztah zkoumaných částí sídelního a pohřebního areálu.

Na západní straně sídelní areál vymezovala zemská stezka vedoucí do prostoru dnešního náměstí (Široký-Nováček-Kaiser 2004, 799). Zatímco archeologický výzkum v pravděpodobné poloze pohřebiště druhého z kostelů naznačil možnost výskytu lidských kostí v objektech sídlištního charakteru (Beneš-Richter 1976, 73, pozn. 15), v prostoru Blochova statku sídelní areál plně respektoval ten pohřební, ležící východně od něj. Vzhledem k chronologickým datům hrobu 14 je možné vzájemné respektování areálů předpokládat již od jejich vzniku. Na rozmezí areálů byla zachycena $\mathrm{v}$ poměrně malém rozsahu část štětované plochy uložené přímo na podloží (obr. 6), která mohla být součástí jejich (symbolického?) vymezení. Dlouhodobé používání pohřebiště potvrzuje i fakt, že odkryté hroby se částečně překrývaly ve stylu etážových hřbitovů obvyklých v mladších obdobích středověku a v novověku. Kostel pak lze zřejmě předpokládat východně od areálu Blochova statku, nejblíže pak v prostoru křižovatky současných ulic Svatopluka Čecha a Za Statkem.

Zánik obou popisovaných sakrálních staveb lze zřejmě dát do souvislosti s odchodem obyvatel osad situovaných u těchto kostelů do nově založeného královského města Plzeň na konci 13. století. K osudu svatyní se vyjadřuje pouze Bonaventura Piter, podle kterého byl kostel sv. Martina zničen pobořením a požáry, z kostela sv. Václava se údajně nedochovaly ani sutiny (Šváb ed. 1988, 54, 86). 


\section{Shrnutí a závěr}

Záchranný archeologický výzkum realizovaný ve Starém Plzenci na místě Blochova statku přinesl několik cenných chronologických zjištění k časovému i prostorovému vývoji levobřežní části někdejší přemyslovské sídelní aglomerace.

Nález denáru Boleslava III. typu C 205 poskytl datum uložení mince do hrobu 14 post quem 1003. Momentálně se jedná o druhou známou existující minci tohoto typu (Lukas-OrnaDudková 2016, 251), která významně doplňuje chronologickou řadu mincí z prrelomu 10. a 11. století vkládaných na českém území do hrobů v rámci pohřebního přechodového rituálu (Lukas-Orna-Dudková 2016, 250). Nalezený denár je i přes mladší narušení hrobu první mincí z prostoru přemyslovské Plzně, kterou lze i přes určité výhrady určit jako obolus mrtvých. Dosud byl jako jediný nález zřejmě získaný z hrobu, který byl součástí pohřebiště u kostela sv. Vavřince na hradě Plzeň, uváděn řezenský fenik vévody Oty II. z doby kolem roku 1253 (Lábek 1921, 46; správné určení mince podle Radoměrský 1955, 27; Švancar 1976, 84). V areálu téhož pohřebiště byly objeveny ještě denár Vladislava I. a denár Soběslava I., u těch se však nepodařilo prokázat souvislost s hrobovým kontextem (Ječný 1920, 64). Většina archeologických výzkumů na hradě Plzeň, které se dotkly prostoru kostelních pohřebišt', proběhla na přelomu 19. a 20. století. Je otázkou, do jaké míry tato skutečnost ovlivnila počet mincí nalezený v hrobech. Současný stav poznání výskytu obolu mrtvých ve Starém Plzenci jen potvrzuje poměrně nízkou nálezovou četnost mincí v hrobech v Čechách (Klápště 1999, 777; Marethová 2008, 11) a dokládá hypotézu, že mince z kostelních hřbitovů se soustřed'ují k přemyslovským hradům (Klápště 1999, 780).

Další absolutní data z hrobu 14, ze kterého pocházel i denár Boleslava III., se podařilo získat díky radiouhlíkovému datování pohřbeného jedince. Jeho úmrtí bylo vymezeno intervalem let 1030-1156. Právě poměrně široké časové vymezení je nevýhodou tohoto chronologického určení. V tomto případě jej však bylo možné komparovat s již zmíněným datem post quem získaným nálezem mince, předpokládaným vznikem kostela sv. Václava v období od poloviny 11. století, kdy také kulminuje četnost mincí ukládaných do hrobu. Chronologická zjištění získaná archeologickým výzkumem přispěla k lokalizaci kostela zasvěceného svatému Václavovi právě ke zkoumanému pohřebišti. Každopádně možnosti radiouhlíkového datování pohřbených jedinců, u nichž byla nalezena mince, může přispět k upřesnění chronologie výskytu obolu mrtvých v českých zemích. Není vyloučeno, že chronologické určení narození, prrípadně smrti pohřbeného jedince, a datum ražby u něj nalezené mince, by mohly osvětlit dosud neznámé skutečnosti, jako je konkrétní význam tohoto artefaktu a jeho př́padná souvislost s přechodovými rituály (Klápště 1999, 780-781; Marethová 2008, 7).

Podle zmínky v listině z roku 1266 byla někdejší osada u kostela sv. Václava součástí města (civitas) vzniklého v prostoru levobřežního suburbia hradu. Vzhledem k tomu, že Stará Plzeň se v mnohém inspirovala Prahou (např. Šolle 2002, 166; Široký-Nováček-Kaiser 2004, 799, 801), lze uvažovat o tom, že impulzem ke zrodu tohoto města mohl být proces vedoucí ke vzniku Pražského Města v průběhu první třetiny 13. století. I ve Staré Plzni se mohly původní osady sjednotit do městské obce, získat výsady od panovníka a domoci se městské samosprávy.

Jak naznačily výsledky výzkumu, stejně jako na dalších místech v levobřežní části přemyslovské sídelní aglomerace dochází k nekatastrofickému zániku osídlení na sklonku 13. století v souvislosti s odchodem obyvatel do nově založeného královského města Nový Plzeň.

\section{Prameny a literatura}

BARTOŠKOVÁ, A., 2013: Obolus mrtvých a jeho význam pro datování archeologických pramenů - Ein

Totenobolus und seine Bedeutung für die Datierung archäologischer Quellen, AH 38, 129-138.

BARTOŠKOVÁ, A.-SLÁMA, J., 1997: Nové mincovní nálezy na Budči, Numismatické listy 52, $150-152$. 
BAŠTA, J.-BAŠTOVÁ, D., 1988: K problematice počátků a vývoje slovanských hradišt’ v západních Čechách, Studia mediaevalia Pragensia 1, 9-31.

BENEŠ, A.-RICHTER, M., 1976: Př́íspěvek k dějinám osídlení Starého Plzence ve 13. století, Sborník Západočeského muzea v Plzni - Historie 1, 67-75.

BERAN, J., 1947: Staroplzeňské kostely. Po stopách zaniklých kostelů ve Staré Plzni, nynějším Starém Plzenci. Praha.

BOHÁČ, Z., 1973: Patrocinia jako jeden z pramenů k dějinám osídlení, ČČH 21, 369-388.

CACH, F., 1970: Nejstarší české mince I. České denáry do mincovní reformy Břetislava I. Praha.

CDB V/1, V/2: Codex diplomaticus et epistolarius regni Bohemiae V/1 (Šebánek, J.-Dušková, S., edd.). Pragae 1974; V/2 (Šebánek, J.-Dušková, S., edd.). Pragae 1981.

CHRONICON THIETMARI, 1996: Thietmari Merseburgensis episcopi Chonicon (Holtzmann, Robert, ed.). Berlin.

DOUBOVÁ, M., 1990: Př́íspěvek k počátkům slovanského osídlení Plzeňska. In: Příspěvky k archeologii západních Čech, Zprávy ČSSA - Supplément 11, 28-54. Praha.

DUDAY, H.-GUILLON, M., 2006: Understanding the circumstances of decomposition when the body is skeletonized. In: Forensic anthropology and medicine (Schmitt, A.-Cunha, E.-Pinheiro, J., edd.), 117-158. New Jersey.

FERNÁNDEZ-JALVO, Y.-ANDREWS, P., 2016: Atlas of taphonomy Identifications. 1001+ images of fossil and recent mammal bone modification. Springer.

FRÝDA, F.-HUS, M., 1989: Archeologický výzkum ve Starém Plzenci - Die archäologische Untersuchung in Starý Plzenec, AH 14, 219-232.

HORNÍK, P.-BLÁHA, R.-SEHNOUTKOVÁ, P.-MAZÁČ, M., 2018: Zdechovice - středověké pohřebiště. AVČ - Supplementum 2. Hradec Králové.

JEČNÝ, J., 1920: Nález denárů na Hůrce nad Plzencem, Plzeňsko 2, 64.

KLÁPŠTĚ, J., 1994: Pamět' krajiny středověkého Mostecka. Most.

- 1999: Př́spěvek k archeologickému poznávání úlohy mince v přemyslovských Čechách - Ein Beitrag zur archäologischen Erforschung der Rolle der Münzen im Přemyslidischen Böhmen, AR LI, 774-808.

- 2003: Dějepis a archeologie: Př́buzenství jak se patří. In: Dějiny ve věku nejistot. Sborník k př́iležitosti 70. narozenin Dušana Třeštíka, 97-109. Praha.

KOLÁŘ, M., 1869: Památky na Plzeňsku, PA VIII, 417-424.

KOMAR, D. A.-BUIKSTRA, J. E., 2008: Forensic Antrhopology. Contemporary theory and practice. New York.

LÁBEK, L., 1921: Kronika památek, Plzeňsko 3, 14-15, 46-47.

LUKAS, J.-ORNA, J.-DUDKOVÁ, V., 2016: Hrobový nález vzácného denáru Boleslava III. C 205 ve Starém Plzenci (okr. Plzeň-město), Numismatický sborník 29 (2015), 248-254.

MARETHOVÁ, B., 2008: Př́íspěvek k poznání raně stř̌edověkých pohřebišt' (zvyk vkládání mincí do hrobů) - A contribution to the knowledge of early medievalcemeteries (coins in graves), Studia mediaevalia Pragensia 8, 7-44.

MERHAUTOVÁ, A., 1971: Raně středověká architektura v Čechách. Praha.

NOVÁČEK, K.-ŠIROKÝ, R., 1996: Starý Plzenec, okr. Plzeň-jih. Předběžná nálezová zpráva pro investora o výsledcích záchranného archeologického výzkumu při rekonstrukci MTS (II. etapa) (1995-1996). Rkp. ulož. v archivu OZAV Západočeského muzea v Plzni, čj. 197/96.

ORNA, J., 2018: Starý Plzenec, Blochův statek, výstavba bytového domu. Rkp. předběžné zprávy ulož. v archivu odd. starších dějin Zpč. muzea v Plzni, čj. HA 79/2018.

PETRÁŇ, Z., 1998: První české mince. Praha.

PINHEIRO, J.-CUNHA, E., 2006: Forensic investigation of corpses in various state of decomposition: A multidisciplinary approach. In: Forensic anthropology and medicine (Schmitt, A.-Cunha, E.-Pinheiro, J., edd.), 159-196. New Jersey.

PROFANTOVÁ, N.-PROFANT, M., 2003: Archeologie a historie aneb ,jak vykopávat dějiny?“. In: Dějiny ve věku nejistot. Sborník k př́iležitosti 70. narozenin Dušana Tř̌štíka, 239-250. Praha. 
Jiří Orna - Veronika Dudková: Př́ínos nálezu denáru Boleslava III. k otázce polohy a vzniku kostelů sv. Václava a Martina ve Staré Plzni

RADOMĚRSKÝ, P., 1955: Bavorský fenik na českém jihozápadě ve 13. století. Nález mincí ve stř́ibře 1953, Numismatický sborník 2, 27-56.

ROŽMBERSKÝ, P., 1998: Hrad Krabotov?, Hláska 9, 13-14.

SMETÁNKA, Z., 1967: Výzkum na předklášterním ostrůvku v Opatovicích nad Labem, AR XIX, 471-477.

STRNAD, J., 1903: O starobylosti a významu Plzence: řeč při slavnosti povýšení Plzence za město 20. července 1902. Plzeň.

SVĚTLÍK, I., 2019: Výsledek radiokarbonového datování. Rkp. ulož. v archivu odd. starších dějin Západočeského muzea v Plzni.

ŠIROKÝ, R.-NOVÁČEK, K., 2014: Transformace Staré Plzně ve 13. století. In: Dějiny města Plzně I. Do roku 1788, 102-122. Plzeň.

ŠIROKÝ, R.-NOVÁČEK, K.-KAISER, L., 2004: Zapomenutá Plzeň. Počátky města pod přemyslovským hradem, AR LVI, 798-827.

ŠNEBERGER, J., 2015: Antropologická zpráva k archeologickému výzkumu raně středověkého pohřebiště na lokalitě „Blochův statek“ ve Starém Plzenci. Rkp. ulož. v archivu odd. starších dějin Západočeského muzea v Plzni.

ŠOLLE, M., 2002: Pilznensis provincia (Příspěvek k otázce založení města Plzně), Sborník Západočeského muzea v Plzni - Historie 16, 164-166.

ŠTAFL, I. K. J., 1957: Terasy řeky Úslavy mezi ústím do Mže a Žinkovy, Sborník Československé společnosti zeměpisné 62, 28-37.

ŠVÁB, M., ed., 1988: Bonaventura Piter. Krátká kronika Staré Plzně. Breve Chronicon Antiquae Plznae. Plzeň.

ŠVANCAR, V., 1976: Nálezy mincí ve Starém Plzenci, Sborník Západočeského muzea v Plzni - Historie 1, 79-87. TUREK, R., 1947: Želenické pohřebiště, Historica slovaca V, 163-183.

ZELENKA, A., 2010: Nálezová zpráva o předstihovém archeologickém výzkumu při stavbě rodinného domu na ppč. 652 a 149/2 ve Vrchlického ulici ve Starém Plzenci (okr. Plzeň-město). Rkp. ulož. v archivu odd. starších dějin Západočeského muzea v Plzni.

- 2012: Nálezová zpráva o předstihovém archeologickém výzkumu při stavbě rodinného domu na ppč. 149/1, 1146 a 1140 ve Vrchlického ulici ve Starém Plzenci (okr. Plzeň-město).

\section{Zusammenfassung}

\section{Der Beitrag des Fundes eines Denars von Boleslav III. zur Frage der Lage und Entstehung} der Kirchen St. Wenzel und St. Martin in Altpilsen

Eine in Altpilsen am Bloch-Anwesen durchgeführte Rettungsgrabung erbrachte einige wertvolle chronologische Feststellungen zur zeitlichen und räumlichen Entwicklung des linksufrigen Teils der ehemaligen přemyslidischen Siedlungsagglomeration.

Der Fund eines Denars von Boleslav III. vom Typ C 205 lieferte als Datum seiner Niederlegung in Grab 14 die Zeit post quem 1003. Momentan handelt es sich um die zweite bekannte existierende Münze dieses Typs, welche die chronologische Reihe von zur Wende des 10. und 11. Jahrhunderts auf böhmischem Gebiet im Rahmen einer Bestattung als Übergangsritual in Gräbern niedergelegten Münzen in bedeutendem Maße vervollständigt. Der gefundene Denar ist auch trotz jüngerer Grabstörungen die erste Münze aus dem Raum des přemyslidischen Pilsens, die mit gewissen Vorbehalten als Charonspfennig (Obolus) bestimmt werden kann. Der gegenwärtige Kenntnisstand über das Vorkommen eines Charonspfennigs in Altpilsen bestätigt nur die verhältnismäßig geringe Häufigkeit von in Böhmen in Gräbern gemachten Münzfunden und belegt die Hypothese, dass Münzen von Kirchenfriedhöfen sich auf přemyslidischen Burgen konzentrieren.

Weitere absolute Daten aus Grab 14 konnten dank einer Radiokarbondatierung des bestatteten Individuums gewonnen werden. Sein Tod wurde auf das Intervall der Jahre 
1030-1156 eingegrenzt. Gerade die relativ breite zeitliche Eingrenzung ist ein Nachteil dieser chronologischen Bestimmung. Im vorliegenden Fall war es jedoch möglich, sie mit dem bereits erwähnten, durch den Fund der Münze gewonnenen Datum post quem, der angenommenen Entstehungszeit der St. Wenzelskirche in der Zeit ab der Mitte des 11. Jahrhunderts zu vergleichen, als auch die Häufigkeit von in Gräbern niedergelegten Münzen kulminiert. Die durch die archäologische Grabung gemachten chronologischen Feststellungen haben dazu beigetragen, die dem heiligen Wenzel geweihte Kirche gerade auf dem untersuchten Gräberfeld zu lokalisieren.

Wie die Untersuchungsergebnisse andeuten, kommt es, ebenso wie an weiteren Stellen im linksufrigen Teil der přemyslidischen Siedlungsagglomeration gegen Ende des 13. Jahrhunderts, im Zusammenhang mit dem Weggang der Bevölkerung in die neu gegründete Königsstadt zu einem nicht-katastrophalen Schwund der Besiedelung.

Mgr. Jiří Orna, Západočeské muzeum v Plzni, Kopeckého sady 2, 30100 Plzeň, Česká republika,jorna@zcm.cz

Mgr. Veronika Dudková, Západočeské muzeum v Plzni, Kopeckého sady 2, 30100 Plzeň, Česká republika, vdudkova@zcm.cz 
